\title{
SUbJECT NATURALISM, SCIENTISM AND THE PROBLEM OF LINGUISTIC MEANING: CRITICAL REMARKS ON PRICE'S "NATURALISM WITHOUT REPRESENTATIONALISM"1
}

\author{
David Macarthur
}

\begin{abstract}
RESUMEN
Huw Price es sin duda uno de los pragmatistas lingüísticos contemporáneos más importantes. Como admirador de su trabajo desde hace mucho tiempo, agradezco la oportunidad de realizar un comentario critico de su inflyente trabajo "Naturalism without Representationalism" (2004) publicado originalmente en un volumen que coedité con mario De Caro titulado Naturalism in Question. Mis comentarios se centrarán en este trabajo suyo; discutiré cualquier otro material incluido en sus otros trabajos tan solo si sirve para aclarar algún aspect de este trabajo. No discutiré ningún desarrollo reciente de la posición anti-representacionalista de Price.
\end{abstract}

Palabras CLAVE: Huw Price, naturalismo, representacionalismo, naturalismo del sujeto, cientificismo.

\section{ABSTRACT}

Huw Price is undoubtedly one of the most important contemporary linguistic pragmatists. As a long-time admirer of his work I welcome this opportunity to critically comment on his influential paper, "Naturalism without Representationalism" (2004), that first appeared in a volume I co-edited with Mario De Caro titled Naturalism in Question. ${ }^{2}$ My comments will be focused mainly on this paper; material from other papers will only be discussed in so far as it helps elucidate themes in this paper. I shall not be discussing recent refinements in Price's anti-representationalist position.

\footnotetext{
${ }^{1}$ Thanks to Talia Morag for her comments on a draft of this paper.

2 This paper is reprinted in Price (2011, pp. 184-199). All page references in the main text are to this book.
} 
KEYWORDS: Huw Price, naturalism, representationalism, subject naturalism, scientism.

\section{SumMARy of Price's ARgument}

Suppose we think, as many contemporary metaphysicians do, that science is our best bet to provide us with an answer to the metaphysical question of what the world is really like. Then various things which we ordinarily think and talk about - moral facts, mathematical facts, meaning facts, mental facts etc. - seem not to be part of the natural world so understood. From this naturalistic point of view they are what we might call problematic items. Orthodox scientific naturalism ("object naturalism") then faces a set of issues that have come to be known collectively as the placement problem: how are we to "place" the problematic items in the natural (or, equivalently, the scientific) world? The standard responses, which are too well-known to require elaboration here, are naturalistic reduction, error theory and expressivism. In line with contemporary metaphysical practice these can be interpreted in semantic terms as proposals concerning our concepts of the problematic items: to reduce them to natural concepts; to eliminate them altogether or retain them as useful fictions; or, lastly, to understand them as having a nonrepresentational function. ${ }^{3}$

In his (2004) Price's basic innovation is to dissolve the placement problem by formulating a different non-metaphysical kind of naturalism that focuses naturalistic attention upon subjects or speakers ("subject naturalism") rather than objects ("object naturalism") -the latter being the orthodox picture. On the standard account, scientific discourse "mirrors" the world as it really is; the metaphysical presupposition being that this discourse is genuinely representational or descriptive discourse. Without this semantic presupposition there would be no placement problem. But this is really a piece of first philosophy -to borrow an expression of Quine's- that is inconsistent with naturalism, which is duty-bound to first empirically investigate the functions of language in different areas without a priori prejudices about which discourses represent the world and how they do so. A naturalistic approach to language is simply part

${ }^{3}$ See, e.g., Jackson (1998). 
of a consistent general naturalism. Object naturalism stands charged with being not naturalistic enough even by its own lights.

This subject naturalist investigation of linguistic function is coupled with a functional pluralism, which accepts Wittgenstein's conception of there being linguistic diversity hidden beneath the surface uniformity of language:

We remain unconscious of the prodigious diversity of all the everyday language-games because the clothing of our language makes everything alike. ${ }^{4}$

By focusing a naturalistic and pragmatic gaze upon linguistic function, on what we do with the various linguistic "tools" (speech acts, concepts) at our disposal, Price argues persuasively that subject naturalism is prior to object naturalism - at least in so far as metaphysics is typically conducted in terms of semantic notions such as truth-makers and referents and the realizers of these semantic roles. In any case object naturalism must be consistent with subject naturalism; but the latter investigation appears to invalidate object naturalism by undermining its representationalist assumptions. At the very least it is an empirical question whether scientific discourse must be understood in representationalist terms (e.g., referents for apparently referring expressions, truth-makers for true sentences) and the availability of minimalist conceptions of truth and reference appears to be all that is needed to capture linguistic practice.

From this new perspective two fundamental themes of object naturalism are discredited: (1) science does not provide an absolute or God'seye-view from which to determine what really exists since there is no such perspective, each discourse or linguistic framework allowing one to formulate existence claims relative to the standards internal to the framework; and (2) there is no theoretically substantial way of drawing a distinction between representational and non-representational, descriptive and non-descriptive; or truth-conditional and non-truth-conditional discourses. ${ }^{5}$ Ordinary thought and

\footnotetext{
4 Wittgenstein (1958, \$224)

5 Since the publication of this paper Price has shifted his position regarding antirepresentationalism. He now distinguishes between e-representations (matters of causal covariance) and i-representations (matters of inferential role) and argues for their independence of each other. The first evidence for this new bifurcation thesis is, I believe, the second Tilburg lecture titled "Two Readings of Representationalism" (2008) [A revised version appears in
} 
talk seems better captured by disquotational theories of truth and reference (or suitable extensions of them ${ }^{6}$, according to which ordinary speakers make no error in speaking of moral, mathematical, mental (etc.) facts, truths or descriptions. But we ought not to read any Platonist ontology off this acknowledgement - which would amount to a mirror-image object non-naturalism.

Semantic terms like "true" and "refers" are theoretically lightweight and readily available wherever we find the appropriate grammatical form no matter what the content of the discourse in question. We may agree with the truth of the sentence "Moral values exist" but still think, like classical expressivists, that the natural function of this sentence is not to describe an aspect of the natural world studied by science or an aspect of a non-natural world in Platonic heaven. What ontological commitments are incurred in speaking in these and other ways is a matter for sociolinguistic inquiry, not metaphysics. Thus, as Price sees it, subject naturalism "offers the benefits of non-naturalism without the metaphysical downside" (p. 133).

Let me examine this subject naturalist plus functional pluralist (aka "global expressivist") position by considering three questions for it: the first concerns where to place subject naturalism in a range of contemporary naturalisms; the second concerns the question of language and meaning within a naturalistic setting; and the third concerns whether subject naturalism is, despite its efforts to resist it, a form of scientism.

\section{What Kind of NATURALism is SubjeCt NATURALism?}

Price explains subject naturalism thus:

... philosophy needs to begin with what science tells us about ourselves. Science tells us that we humans are natural creatures, and if the claims and ambitions of philosophy conflict with this view, then philosophy needs to give way. (p. 186)

How we interpret this remark depends upon how we construe the crucial term "natural". Part of the problem of critically examining Price's paper

Price (2013)]. But I shall leave this refinement of his position aside since nothing turns on it for the purposes of this paper.

${ }^{6}$ Price's convenient friction account, unlike the disquotational theory, recognizes the normative role of truth. See "Truth as Convenient Friction" in Price (2011, pp. 163-183). 
is that certain key terms upon which his argument turns are left either undefined or vaguely defined. These include "science", "natural", and "natural world".

Does "science" refer to natural science only or both the natural and human sciences? Price is unclear on the matter and one can point to texts that support each of these readings. ${ }^{7}$ This matters when it comes to how expansive the scientific image is, which, in turn, has a fundamental bearing on the placement problems of object naturalism that subject naturalism promises to resolve. Broader conceptions of the scientific image threaten to close the gap between it and the manifest image, which would undermine the original motivation for the placement problem.

More important for present purposes is the question what "natural world" is supposed to refer to? It seems most plausible to read what Price calls "natural reality" as the scientific image of reality, since he is appealing to this conception to explain the placement problem: the naturalistic problem of how to find a place in reality, so construed, for the problematic items (p. 187). Taking this as our clue, then, we can understand the key term "natural" as something along these lines: amenable to scientific study and explicable in scientific terms.

Now the first sentence of the conjunct above reads: science tells us that we bumans are natural creatures i.e. amenable to scientific study and to being fully explained in scientific terms. In the case of human beings, then, subject naturalism coincides with object naturalism, which is committed to a purely scientific ontology and purely scientific forms of knowledge and understanding. But the sentence is, in fact, false. Science has not shown that persons qua rational agents are fully understandable, or completely explicable, in scientific terms.

For one thing reason has not been naturalized.' Indeed since science is an objective inquiry into the natural world then, rather than thinking that it explains the world in its fullness, science simply abstracts away from whatever does not fall within its purview. Examples of non-scientific items that are not

\footnotetext{
${ }^{7}$ For a defense of the narrower reading see, e.g., (p. 132, fn 1); for a defense of the broader reading note that Price sometimes refers to the stance of the subject naturalist as "anthropological", e.g., (p. 254).

8 See Macarthur (2010). Even broader conceptions of the scientific image are generated if one considers the objects presupposed by scientific practice as well as the explicit objects of scientific inquiry.

${ }_{9}^{9}$ Putnam (1983). Fodor (1997).
} 
fully amenable to scientific study include people (understood as rational agents), actions (in the Anscombian sense of something done under a description for a reason), art (understood as having intentional content), reasons (understood as irreducible conceptually normative items), buman bistory (understood as the history of human action), ordinary artifacts (whose identity conditions are interest relative) and much else. All of these only become fitting objects of scientific study if we re-conceive them according to concepts whose conditions of individuation accord with appropriate scientific standards of impersonality and determinacy. ${ }^{10}$ For example, a person qua living body can, of course, be studied by a physiologist or biochemist.

Let us compare subject naturalism to liberal naturalism, a non-scientistic form of naturalism subscribed to by Strawson, Putnam, McDowell, amongst others. ${ }^{11}$ According to the latter form of naturalism we should not identify the natural with the scientific; and so, we should not contrast the natural with the non-scientific. The relevant contrast is, instead, with the supernatural. To say we are natural creatures then gets its bite from dialectical opponents who suppose that we have immortal souls or magical powers and suchlike. Indeed, from the liberal naturalist perspective, persons belong to the category of natural nonscientific items that are routinely overlooked in contemporary philosophy which is blinded by various forms of scientism. This category of things is of particular interest to the liberal naturalist who explores the conceptual space between scientific naturalism and supernaturalism.

Given his metaphysical quietism -according to which nothing counts as an absolute perspective (certainly not science!) from which to conduct the traditional metaphysical inquiry of Ontology ${ }^{12}-$ one would have thought that Price's subject naturalism is a form of liberal naturalism. That is, a theory which accepts the existence of non-scientific forms of understanding and of natural non-scientific items. Price writes, for example, that the perspective of science is simply one perspective amongst many others,

[Subject naturalism] imagines a scientific discovery that science is not all there is - that science is just one thing among many that we do with "representational" discourse. (p. 199)

10 See, e.g., Quine (1981).

${ }^{11}$ See the two collections exploring the philosophical program of liberal naturalism: Mario De Caro \& David Macarthur (eds.) (2004) and (2010).

${ }^{12}$ Here Price reveals himself as a keen student of Carnap at his anti-metaphysical best. 
On this picture scientific inquiry abstracts away from various items in the world that are recognized in other discourses or forms of inquiry, say, moral, aesthetic, and political. If we suppose people (qua rational agents) are one of the items science abstracts away from then we are not, after all, natural creatures in the sense that Price intends. This will be so in so far as we are not fully understandable in scientific terms. But being non-scientific in this sense is, of course, consistent with being natural in the other sense (i.e. nonsupernatural) and being amenable to scientific inquiry under various partial redescriptions.

Price's claim that we are natural creatures is not a simple slip, however. It is testament to his denial that subject naturalism need admit any nonscientific (for him, non-natural) entities. In a review of Blackburn, Price writes,

Non-naturalists contend that there is more to reality than natural reality (or, what amounts to the same thing... that the bounds of the natural are wider than first supposed). ${ }^{13}$

Price is unambiguous in his rejection of this option as "involv[ing] a kind of metaphysical fairy story". ${ }^{14}$ To accept non-scientific items would be the metaphysical downside that he thinks subject naturalism saves the unreconstructed non-naturalist from. But the liberal naturalist can recognize non-scientific items (non-natural realities in Price's sense) without engaging in metaphysical fairy-tales. The bounds of the natural (=non-supernatural) are indeed wider than scientific inquiry would lead us to think. Science is an abstraction from a richer world.

Although the denial that science is an absolute perspective suggests subject naturalism is a form of liberal naturalism, Price's considered opinion seems to be that while talk of the existence of persons, actions, art, moral values, etc. is legitimate - this is the salve for non-naturalists - it must still be naturalistically explained in such as a way as to be consistent with nothing over and above a suitably scientific ontology. The scientific ontology countenanced by subject naturalism is likely to diverge from the scientific image of object naturalism, of course, given that the subject naturalist's version will be the

13 Price (1996, p. 966).

14 Ibid. 
result of an empirically-based functional explanation of scientific discourse itself. $^{15}$

We can conclude that subject naturalism is not a form of liberal naturalism. Indeed there is considerable tension between Price's impartial treatment of linguistic perspectives, of which science is only one, and the idea that subject naturalism provides a general philosophical position which gives a preeminent role to a scientific (read: a biological or anthropological (p. 294, p. 320)) account of linguistic function. I shall return to this point below.

\section{The Problem with a (Subject) Naturalist approach to LANGUAGE}

Subject naturalism is a linguistic naturalism, a form of philosophy that begins with a scientific inquiry which asks, in the manner of an anthropologist or biologist, what functions are served by various speech acts (e.g. assertion) and concepts (e.g. truth). ${ }^{16}$ Like Wittgenstein, Price is a functional pluralist who recognizes that there are many different functional differences served by different regions of language despite the fact that all discourses partake of the same "representational" apparatus of propositional form, truth-aptness, logical relations (etc.).

A key question for Price is whether the linguistic data for the subject naturalist is language qua meaningful utterance or language qua marks and noises. The first is characterized in semantic, normative and intentional terms; the latter not. As Quine saw, science can only accept as data those objects or events whose conditions of individuation and verification meet objective standards

\footnotetext{
${ }_{15}$ Price (2011, pp. 142-3) mentions the centrality of causal and modal notions in science both of which cannot be straightforwardly understood in terms of responses to objects of scientific study.

16 Two problems that I shall not discuss here arise for the biological or anthropological functional explanations of linguistic practice offered by the subject naturalist: (1) the general functions imagined by this form of inquiry may not exist in so far as subject naturalism is, so far, mere armchair scientific speculation and local functions (or uses) are available; and (2) even if there are the general functions that subject naturalism imagines, there is a further question whether they are sufficiently fine-grained to capture conceptual differences we pre-theoretically recognize. For example, Price hypothesizes that the function of truth is to make disagreements matter. But is the functional idea that we benefit from "pooled cognitive resources" (177) not equally applicable to truth-involving concepts like knowledge and judgment? For more discussion see Macarthur (2014).
} 
where the relevant conception of objectivity is a matter of determinacy, public accessibility and reproducibility. ${ }^{17}$ Scientific data must be available for, and scientific results must be verifiable by, all scientific inquirers. It is for this reason that Quine, and following him, Horwich, take it that the only available linguistic data from the point of view of science is language qua marks and noises; a range of naturalistically respectable physical shapes and sounds. ${ }^{18}$

Price shows a clear recognition of this point by his inclusion of meaning facts amongst those items that raise a placement problem for object naturalism. ${ }^{19}$ In other words, meaning facts are not part of the scientific image of the world. But the problem for Price is that the linguistic 'objects' he wishes to study are, precisely, meaning facts only manifest at the level of meaningful discourse. ${ }^{20}$ This is the level at which there are speech acts which employ various conceptual resources in producing, say, assertions. A characterization of language in terms of marks and noises is orthogonal to a characterization in terms of meaningful utterance. One cannot derive the latter from the former. From a bare description of language qua marks and noises not only is one unable to tell what is meant, one is not even in a position to say that anything is meant! $!^{21}$ Language qua meaningful utterance is a natural non-scientific item, which is not amenable (so construed) to naturalistic study. As Quine noted, meanings are too vague, interest-relative and subjective to be fit objects of scientific study. But it is meaningful language in this sense that is the supposed object of subject naturalist inquiry.

It might be imagined that Price has managed to sidestep this problem by invoking Wittgenstein's dictum that meaning is use. Price's reasoning appears to run as follows: use can presumably be characterized in terms of human behaviour and since behaviour is an object of naturalistic study so, too, is

\footnotetext{
17 This leads Quine to the view that language is ultimately a matter of the stimulation of sensory receptors. See, e.g., (1992, p. 19).

${ }_{18}$ Quine (1992, ch. 1). Horwich (2005).

19 Price (2011, p. 133) notes that the linguistic functions hypothesized by the subject naturalist must be "characterized in acceptably naturalistic terms". But the same point, of course, applies to the data for this sort of theorizing.

20 Price (1997) acknowledges this point in a paper criticizing Horwich's Quinean conception of language in terms of marks and noises. But, as I argue here, it is not clear that Price himself is entitled to any other conception of the linguistic data.

${ }^{21}$ For further discussion of the importance of intelligible discourse as a presupposition of subject naturalist inquiry see Macarthur (2014).
} 
meaning. But the same naturalistic shift we noted with regard to "language" is also evident in Price's use of the terms "use" and "behaviour". In each case there is a crucial shift from a semantic, intentional (non-scientific) conception to a non-semantic, non-intentional (scientific) conception. The relevant notion of $u s e$ for the purposes of understanding meaning is normatively-loaded ordinary use as manifest in the linguistic practice of masters of the relevant language. This is not mere behaviour characterized in the naturalistic terms of physical movements or biological states. The relevant notion of use is a matter of communicative actions, which are intentional performances done for various reasons. Ordinary use of meaningful language is thus distinct from the scientific function of physical marks and noises.

The relevant notions of language, meaning, use, and action are all natural non-scientific notions. None of them are fitting objects of naturalistic study without changing one's theoretical focus through naturalistic re-description. This unfitness arises in part because all of these notions implicate a naturalistically irreducible conception of rational or conceptual normativity. Concept use is governed by norms of correctness that are not reducible to naturalistic categories. For this very reason both Wittgenstein and Brandom, two of Price's inspirations in the field of linguistic pragmatism, begin with a normative characterization of linguistic practice. ${ }^{22}$ In Price's invocations of Wittgenstein and Brandom as precedents for his own view, this important point goes missing.

One might attempt to rescue Price's position by supposing that his subject naturalist can simply appeal to ordinary use in characterizing the linguistic data. But, although this is not apparent in the (2004) paper under review, what the subject naturalist presumes to offer is an immodest theory of language, one that does not presuppose that the theorist understands, or can use, the language that he or she is studying. ${ }^{23}$ But the presumption of immodesty is surely wrongheaded.

Just as object naturalism presupposes subject naturalism so, too, subject naturalism presupposes ordinary use - on pain of having no linguistic

\footnotetext{
22 Brandom (1994). Wittgenstein (1958). And Wittgenstein, unlike Brandom, never attempts to explain intentional content in terms of prior normative statuses.

${ }^{23}$ See "Immodesty without Mirrors" in Price (2011, pp. 200-227). John McDowell (1998, p. 87) explains a modest theory of language as one that relies on a native speaker's grasp of at least "the concepts expressed by the primitive terms of the language."
} 
data of the right kind to theorize about. And just as subject naturalism undermines the representationalist presuppositions object naturalism so, too, a Wittgensteinian (or liberal naturalist) study of ordinary use undermines the theoretical pretensions of subject naturalism in so far as the latter is committed to immodesty and recognizing only scientific objects. The trouble for the subject naturalist is that admitting this kind of dependency on ordinary use seriously compromises the claim that it is a "serious science" (p. 116, p. 257).

\section{The Role of Science in Philosophy: Is Subject NATURALISM STILL A FORM OF SCIENTISM?}

Let us return to Price's explanation of subject naturalism,

... philosophy needs to begin with what science tells us about ourselves. Science tells us that we humans are natural creatures, and if the claims and ambitions of philosophy conflict with this view, then philosophy needs to give way. (p. 186)

Here I want to consider in greater depth the relation of science and philosophy that is envisaged here. Price's conception of philosophy owes a large debt to Quine who famously remarked that "philosophy is continuous with science". ${ }^{24}$ As we have seen, Price treats subject naturalism as serious science; indeed, since, like Quine, he does not care to draw a line between philosophy and science, it is conceived as "science... in philosophy" (p. 199).

Price elaborates this vision as follows,

What is philosophical naturalism? Most fundamentally, presumably, it is the view that natural science constrains philosophy, in the following sense. The concerns of the two disciplines are not simply disjoint, and science takes the lead where the two overlap. At the very least, then, to be a philosophical naturalist is to believe that philosophy is not simply a different enterprise from science, and that philosophy properly defers to science, where the concerns of the two disciplines coincide. (p. 184)

But if there is no drawing the line between science and philosophy then one cannot take Price's advice to defer to science where the two overlap since

${ }^{24}$ Quine (1975, pp. 125-6). 
to do that presupposes one can draw a useful line between them. At the very least Price owes us further clarification about the difference(s) between philosophy and science. Moreover, where science raises interpretative problems it is not at all clear why philosophy must defer to science. Why are both not on an equal footing, say, when it comes to how best to interpret quantum mechanics, for example? ${ }^{25}$ One might fully concur with Quine, Putnam and Rorty that philosophy can no longer presume to sit in judgment of other disciplines from an imagined God's-eye-view of the world; but the right response to that need not be to say the philosophy's role is beneath that of science. That Price takes it to be so is one indication of a lingering scientism in his position.

It is true that Price works hard to avoid the charge of scientism that paradigmatically characterizes object naturalism. As we have seen, he appeals to functional pluralism, the idea that science is one linguistic perspective amongst others, in explaining how the scientific image of the world does not raise placement problems for moral values, meanings, mental states etc. Each of these things is countenanced from standards internal to their own discourses. The scientific view of the world has no absolute primacy but only a perspectival primacy, as Price explains,

... as functional pluralists, we speak from within the scientific framework but about other frameworks. This gives the scientific framework a kind of perspectival primacy. Our viewpoint is internal to science but external to morality, for example. (p. 142)

But while Price recognizes a plurality of linguistic frameworks of which the scientific is only one, the scientific framework does have a special kind of priority because it is from this framework that one practices philosophy! The scientific framework has philosophical primacy: it is the position from which one articulates one's worldview. Subject naturalism explains the functions of all linguistic frameworks and in so doing gives us a picture of the world. It, therefore, bears an asymmetrical explanatory relation to other frameworks. Whatever theoretical reflection non-scientific frameworks involve is subject to functional re-description by way of the explanations propounded by subject

${ }^{25}$ For a fine discussion of interpretative problems that arise for fundamental physical theory see Sklar (2001). 
naturalist inquiry. The subject naturalist sits in judgment of the function of all other discourses, including their theoretical aspects. This is enough to convict Price of scientism contre lui.

The primacy of subject naturalist functional explanation also leads to a primacy of whatever scientific ontology is presupposed in giving these explanations. It is not an absolute a priori kind of primacy, of course; but an empirically-defeasible philosophical primacy, nonetheless. While Price's subject naturalism is happy to countenance such truths as "Moral values exist" the functional explanation of this sentence does not posit moral values as part of the natural world. Rather, the subject naturalist is a global expressivist who helps himself to the sorts of positive explanations of linguistic function offered by local expressivists except now applied across all discourses - of course, without the traditional denial of truth or factuality that once gave life to the now defunct doctrine of non-cognitivism. Talk of moral values is understood in terms of expressions of various sort of psychological attitudes, for examples. ${ }^{26}$

In other words, on Price's view, moral values are not needed to provide causal explanations of our talk of moral values. And the same will hold for our talk of all the other problematic items: numbers, meanings, reasons etc. since none of these are causal notions. Thus Price retains moral truths, say, but not a face-value understanding of them. Ordinary folk can rightly say that there are moral values but the theorist explains such talk without positing moral values. ${ }^{27}$

Consequently, the entities science recognizes in its causal-functional explanations are given a certain priority in Price's explanatory program. And this is the basis of the primacy accorded a specifically scientific ontology. The primacy in question here is not threatened by the observation that a good deal of scientific discourse itself - including modal and causal idioms - will not figure in the natural world. ${ }^{28}$ All that shows is that the scientific ontology of

26 Although Price likes to trade on the move of globalizing the sorts of explanations offered by classical expressivists there is a crucial aspect of their view that he means to avoid. Traditional non-cognitivists were interested in linguistic functions describable at the ordinary psychological level of meaningful discourse in terms of expressing various emotions or evaluative attitudes like resentment. In so far as intentionality is naturalistically irreducible Price must deny that it is functions in this sense that are the concern of subject naturalism.

${ }^{27}$ This helps to explain the echoes of instrumentalism in Price's account even if Price is adamant that his account does not accuse ordinary practice of any error.

28 See Price (2011, pp. 142-3). 
subject naturalism is distinct from the scientific ontology of object naturalism built as it is on questionable semantic presuppositions. The subject naturalist's ontology remains a scientific ontology for all that. Consider this passage,

The fact that there are no moral properties in the natural world does not entail that moral talk is in error, if its function is not to describe such properties. Inquiring into its function we find (let us suppose) that it is to give voice to certain mental states, distinguished by their motivation role in human psychology. Suppose... that this function is one of those appropriately served by the core properties of the descriptive language. This would explain why moral discourse takes descriptive form, and hence why it involves truth claims and existence claims. We would thus have a naturalistic understanding of what speakers are doing when they engage in moral discourse, and hence a reason to deny that such speakers are guilty of some global error, without any concession about the descriptive function of the moral discourse. (p. 141)

It is all very well to accept full-voice that there are moral facts, mathematical facts, meaning facts, facts of reason etc. since this says no more than that certain sentences are accepted as true - "facts" here being a linguistic notion equivalent to true propositions. ${ }^{29}$ The functions of these different discourses (each a topic for subject naturalist inquiry) are, by hypothesis, all well served by the core properties of descriptive discourse (another topic for study): assertoric language is, in a favourite Wittgensteinian metaphor, a "multi-purpose tool" (p. 222). ${ }^{30}$ But it is quite another thing to accept that there are moral values, meanings, reasons etc. on a face-value understanding, which does not explain away these existential locutions in other terms from the theoretical stance.

Subject naturalism is committed to this explaining-away strategy as Price's remarks above make clear. We are right to say there are moral truths (properties, facts, descriptions) but this is explained theoretically in such a way that "there are no moral properties in the natural world". That is, moral properties are not needed to causally explain our talk about them. No other ground of their worldly existence is considered. Despite the linguistic

\footnotetext{
${ }^{29}$ See Price (2011, p. 164, fn. 1).

${ }^{30}$ In a number of places Price suggests that the best account of the core property of assertoric discourse is Brandom's account in terms of giving and asking for reasons. For example see (Macarthur \& Price, 2011, p. 247).
} 
sophistication, the resulting picture is surprisingly traditional in its denial that the problematic items (according to object naturalism) are features of the natural world.

It may help to clarify this picture to compare it with that of the liberal naturalism of Thomas Scanlon. ${ }^{31}$ For him, too, our talk of moral truths (facts, descriptions) is not some sort of global error - indeed, in many cases we are right to talk in this way. For him, too, moral values are not, and do not purport to be, part of any of the causal orders studied by the sciences. But moral values are part of the 'natural' world understood in liberal naturalist terms as the nonsupernatural world, not the scientific world. Our talk of moral values needs no legitimation from either science or metaphysics. This is not a mere verbal disagreement about how to understand the expression "natural world", however. It reflects a significant bias in Price's position against acknowledging, in one's theoretical voice, the existence of abstract items that are not part of a causal structure studied by science. For Scanlon the test of whether moral values are part of the natural world is simply that "they are matters we discover the truth about simply by thinking about them in the right way". "The fact that moral values do not figure in causal explanations of our talk about them is no grounds for a denial that they are part of the natural world that we think and theorize about.

The idea that the world includes moral values, literally speaking, on the basis of our rational sensitivity to them -an idea also defended admirably by McDowell ${ }^{33}$ - is dismissed by Price as a non-naturalist fairy-tale. ${ }^{34}$ But what the subject naturalist dismisses as non-natural ( $=$ non-scientific) a liberal naturalist can countenance as part of an expanded conception of the natural (=nonsupernatural) world because a liberal naturalism allows for both causal and rational responsiveness in its explanations of how language operates. That Price's functional explanations are really causal explanations (on a suitably

\footnotetext{
${ }^{31}$ See "Metaphysics and Morals" in De Caro \& Macarthur (2010, ch. 9)

32 De Caro \& Macarthur (eds.) (2010, p. 175).

${ }^{33}$ McDowell (1998b, pp. 50-76).

34 Of course it is a serious question how, say, moral values unlike causal entities such as stones and trees, can be both mind-dependent, in some sense -thereby, avoiding the charge of Platonism-and yet objective enough to sustain our critical practices. Here one promising suggestion is to appeal to social relations of mutual recognition -a strategy one can find in Hegel, Cavell and Brandom.
} 
pluralistic conception of causal relations) is another sign of the residual scientism in the subject naturalist plus global expressivist worldview.

David Macarthur

The University of Sydney

david.macarthur@sydney.edu.au

\section{REFERENCES}

Brandom, R. (1994), Making It Explicit, Cambridge, Mass: Harvard University Press.

De Caro, M. \& Macarthur, D. (2004), Naturalism in Question Cambridge, Mass: Harvard University Press.

--(2010), Naturalism and Normativity, Cambridge, Mass: Harvard University Press.

-(2014), "What's the Use? Price \& Wittgenstein on Naturalistic Explanations of Language", Al-Mukhatabat Journal: Special issue on Wittgenstein, No. 9, pp. 77-95.

FODOR, J. (1997). "Special Sciences: Still Autonomous After All These Years." Philosophical Perspectives, vol. 11, pp. 149-163.

Horwich, P. (2005), Reflections on Meaning, Oxford: Oxford University Press.

JACKSON, F. (1998). From Metaphysics to Ethics, Oxford: Clarendon.

Macarthur, D. (2010), "Taking the Human Sciences Seriously" in De Caro \& Macarthur (eds.) (2010), pp. 123-141.

-(2014), "What's the Use? Price \& Wittgenstein on Naturalistic Explanations of Language", Al-Mukhatabat Journal: Special issue on Wittgenstein, vol. 9, 77-95.

McDowell, J. (1998a), Meaning, Knowledge and Reality, Cambridge, Mass: Harvard University Press.

(1998b), Mind, Value and Reality, Cambridge, Mass: Harvard University Press.

Price, H. (1996), "Review of Essays in Quasi-Realism by Simon Blackburn", Philosophy \& Phenomenological Research vol. 56, pp. 965-968.

(1997), "What Should a Deflationist about Truth say about Meaning?", Villanueva, E. (ed.), Truth (Philosophical Issues, Vol. 8), Ridgeview. 
(2011), Naturalism Without Mirrors. Cambridge, Cambridge University Press.

(2013), Expressivism, Pragmatism and Representationalism. Cambridge: Cambridge University Press.

Putnam, H. (1983), "Why Reason Can't be Naturalized" in Realism and Reason: Philosophy Papers Vol. 3. Cambridge: Cambridge University Press, 1983, 229-247.

QuinE, W. V. O. (1975), “The Nature of Natural Knowledge”, in Samuel Guttenplan, ed. Mind and Language, Oxford: Oxford University Press, 67-81.

(1981), Theories and Things. Cambridge, Mass: Harvard University Press.

(1992), Pursuit of Truth (Revised Ed.) Cambridge, Mass: Harvard University Press.

SCANlon, T. (2010), "Metaphysics and Morals" in De Caro \& Macarthur (2010).

SKLAR, L. (2001), "Naturalism and the interpretation of Theories", Proceedings of the $A P A$, vol. 75 , no. 2, 43-58.

WitTGenstein, L. (1958), Philosophical Investigations [1953], Oxford: Blackwell. 